\title{
Taxonomy and Nomenclature of Baldcypress, Pondcypress, and Montezuma Cypress: One, Two, or Three Species?
}

\author{
Geoffrey C. Denny ${ }^{1,3}$ and Michael A. Arnold ${ }^{2}$
}

ADDITIONAL INDEX WORDs. scientific name, binomial, variety, subtaxa, Taxodium distichum var. distichum, var. imbricarium, var. mexicanum, Taxodium ascendens var. nutans, Taxodium mucronatum

SumMARY. As interest in issues such as seed source, provenance, genetic pollution, and threatened and endangered plant species grows, so does the need for an understanding of the relatedness and evolutionary history of plants. Appropriate taxonomy and nomenclature become much more important. Taxodium (L.) Rich. is a genus of landscape trees included in many plant materials courses across the country. It has been treated variously in the horticulture literature as having one, two, or three species. The most appropriate treatment is one species with three botanical varieties: baldcypress [Taxodium distichum (L.) Rich. var. distichum], pondcypress [T. distichum var. imbricarium (Nutt.) Croom], and montezuma cypress [T. distichum var. mexicanum Gordon].

$\mathrm{T}$ he appropriate taxonomy and nomenclature for plant taxa (taxonomic groupings) are often overlooked by the nursery industry and may seem of little importance. However, names frequently do not reflect the most current taxonomic classification. This may seem of little importance. However, names take on a new importance when we realize that binomials are intended to convey information beyond distinguishing one plant from another. Binomials reflect relationships and relatedness among groups of plants. We ignore that information if we do not use the most appropriate name as decided by a taxonomic specialist. Ecologically and environmentally friendly industry practices are growing in importance along with public interest. Issues such as provenance are receiving more and more interest and research (Bresnan et al., 1996; Giridhar et al., 1995; Lickey et al., 2002; McMillian, 1974; Schrader and Graves, 2000; Shoemake et al., 2004; Wood et al., 1998). Appropriate classification of taxa is of the utmost importance in these types of studies, because they attempt to investigate the geographic component to genotypic variation. Erroneous conclusions may be drawn if

Department of Horticultural Sciences, Texas A\&M University, College Station, TX, 77843-2133.

${ }^{1} \mathrm{PhD}$ student.

${ }^{2}$ Professor of Landscape Horticulture.

${ }^{3}$ Corresponding author. E-mail: gcdenny@tamu.edu incorrect taxonomic classification is used.

Often horticulturists are frustrated, irritated, and sometimes baffled by the seemingly arbitrary nomenclatural changes taxonomists and systematists make to plants. We often wonder aloud, "Why can't they just leave things alone?" We often ask students the importance of scientific names while teaching plant materials classes. Answers range from "because plants can have more than one common name" to "so each plant has a standard name that everyone uses." Almost invariably the answers deal with distinguishing plants from each other. We spend very little time on the importance of scientific names for conveying relatedness among plants or evolutionary history of taxa. Yet, this is the objective of the hierarchical system Linnaeus created. Otherwise, all that would matter is that each taxon has a unique name. Name changes are not always meaningful if all we are concerned with is distinguishing one plant from another. However, as interest grows for issues like seed source, provenance, genetic pollution, and threatened and endangered plant species, so does the need for an understanding of the relatedness and evolutionary history of plants. Correct plant nomenclature becomes more important regarding to which genus a species belongs or whether two taxa are distinct species or subspecies or botanical varieties. Names must adhere to the nomenclatural rules set by the International Code of Botanic Nomenclature (Greuter et al., 2000), including those dealing with status, typification, and priority of names.

There are several very useful online nomenclatural data bases that are readily accessible. These include the International Plant Names Index (2006), the Missouri Botanical Garden's VAST nomenclatural database accessed through the $\mathrm{W}^{3} \mathrm{TRO}$ PICOS interface (Missouri Botanical Garden, 2006), and the U.S. Department of Agriculture (USDA) National Plant Germplasm System (USDA, 2006).

\section{Taxonomy of Taxodium}

Baldcypress, pondcypress, and montezuma cypress are three taxa recognized historically in the genus Taxodium. Baldcypress has a range along the Atlantic and Gulf Coast Plains of the United States. It can be found naturally as far north as Maryland and Illinois, and south into Florida and central Texas (Middleton and McKee, 2004). Pondcypress is restricted in distribution to Florida and the Gulf Coast east of Texas, and up the Atlantic coast to North Carolina (Middleton and McKee, 2004). Montezuma cypress is the southernmost taxa, occurring in Mexico and far southern Texas (Turner and Watson, 1999).

T. distichum is widely accepted as the correct name for baldcypress (Arnold, 2002; Liberty Hyde Bailey Hortorium, 1976; Lickey and Walker, 2002; Lickey et al., 2002; McMillian, 1974; Murphy and Stanley, 1975; Schopmeyer, 1974; Tsumura et al., 1999; Turner and Watson, 1999; Vines, 1960; Watson, 1983, 1993). Disagreement arises with respect to the classification of the other two taxa. Authors treat the genus as having three species (Arnold, 2002; Griffiths, 1994; Krüssmann, 1985; Turner and Watson, 1999); others, as two species, with one having two botanical varieties (Liberty Hyde Bailey Hortorium, 1976; Vines, 1960). Pondcypress has been treated as a distinct species, $T$. ascendens Brongn., by some authors (Arnold, 2002; Griffiths, 1994; Krüssmann, 1985; Turner and Watson, 1999) and as a botanical variety of $T$. distichum by 
others (Liberty Hyde Bailey Hortorium, 1976; Lickey and Walker, 2002; Lickey et al., 2002; Murphy and Stanley, 1975; Schopmeyer, 1974; St. Hilaire, 2001; Vines, 1960; Watson, 1983, 1993). The botanical variety name most commonly assigned is T. distichum var. nutans (Ait.) Sweet. Pondcypress has been segregated from baldcypress based on vegetative morphology, sometimes in combination with poorly defined and inconsistent habitat or community-type differences (Watson, 1983). Watson (1983) reported that there exist numerous individuals and populations that "exhibit morphological intermediacy or curious admixtures of the characters representative of the morphological extremes. (p. 192)" This phenomenon has also been personally observed by the authors of this paper. Watson (1983) contends that the vegetative and ecological differences are insufficient to support specific rank for pondcypress. Also, there is no significant difference in reproductive morphology and anatomy, embryology, leaf flavonoid and bioflavonoid profiles, and nuclear DNA content of meristematic root cells (Watson, 1983). All these characters have been reliable criteria for distinguishing between species of other conifers (Watson, 1983). Therefore, Watson (1983) classified pondcypress as a botanical variety of T. distichum. Also, Tsumura et al. (1999) concluded that pondcypress should only be given botanical variety status based on DNA analysis using cleaved amplified polymorphic sequences. Based on allozyme analysis, botanical variety status for pondcypress was also supported by Lickey and Walker (2002).

Montezuma cypress is often treated as a distinct species, $T$. mucronatum Tenore (Arnold, 2002; Liberty Hyde Bailey Hortorium, 1976; Creech and Yunlong, 2003; Griffiths, 1994; Krüssmann, 1985; McMillian, 1974; St. Hilaire, 2001; Turner and Watson, 1999; Vines, 1960). However, according to Watson (1983) it has also been treated as a botanical variety, $T$. distichum var. mexicanum Gordon. DNA and phytochemical analyses are not available for montezuma cypress. However, there are several factors that suggest botanical variety status is appropriate. Montezuma cypress differs only by "minor phe-

Table 1. Key to botanical varieties of Taxodium distichum.

la. Determinate short shoots mostly ascending in a vertical plane; awllike leaves narrowly lanceolate, 0.1-0.4 inch long, appressed, and imbricate in five to eight ranks on shoots. . . . . . . . . . . . . . . . . . . . . var. imbricarium

1b. Determinate short shoots mostly spreading in a horizontal plane; flattened leaves narrowly linear, $0.2-0.6$ inch long, divergent, and appearing two ranked on shoots. . . . . . . . . . . . . . . . . . . . . . . . . . 2

2a. Leaves deciduous; branches (catkins) containing male cones short and crowded, often divided into compact secondary branches..............var. distichum

2b. Leaves semievergreen; branches (catkins) containing male cones long and slender, open, made up of single cones or clusters of several cones ....... var. mexicanum

${ }^{\mathrm{z}} 1$ inch $=25.4 \mathrm{~mm}$.

Adapted from Watson (1983) and Correll and Johnston (1970).

nological characters," as indicated by Watson (1993) in his treatment of Taxodium for the Flora of North America. McMillian (1974) indicated morphological and physiological gradients exist between $T$. distichum and the Mexican populations. Montezuma cypress has been planted in close proximity in areas of central Texas to native baldcypress stands. Large numbers of offspring with intermediate characteristics and heavy seed set were observed there in the fall 2003 (G. C. Denny, pers. obs.). These observations, in the absence of molecular evidence, indicate that botanical variety status is more appropriate for montezuma cypress. See Table 1 for a key to the botanical varieties of $T$. distichum.

Table 2. Abbreviated synonymy for baldcypress, pondcypress, and montezuma cypress.

Baldcypress

1810. Taxodium distichum (L.) Richard var. distichum

1810. Taxodium distichum (L.) Richard

1753. Cupressus disticha L.

1789. Cupressus disticha var. nutans Aiton

1827. Taxodium distichum var. nutans (Aiton) Sweet

1938. Taxodium distichum f. confusum Palmer and Steyermark

1939. Taxodium distichum f. pendens Rehder

Pondcypress

1837. Taxodium distichum var. imbricarium (Nuttall) H.B. Croom

1818. Cupressus disticha L. var. imbricaria Nuttall

1833. Taxodium ascendens Brongniart

1902. Taxodium imbricarium (Nuttall) R.M. Harper

1927. Taxodium ascendens var. nutans (Aiton) Rehder, pro synonym, non Aiton

Taxodium ascendens var. nutans (Aiton) Sweet, sensu authors, non Aiton

1982. Taxodium ascendens ssp. nutans (Aiton) E. Murray, pro synonym, non Aiton

\section{Montezuma cypress}

1858. Taxodium distichum var. mexicanum (Carrière) Gordon

1855. Taxodium mexicanum Carrière

1853. Taxodium mucronatum Tenore

1854. Taxodium montezumae Decaisne

1906. Taxodium distichum var. mucronatum (Tenore) A. Henry 
nutans was originally described by Aiton (1789) and C. disticha var. imbricaria by Nuttall (1818). It appears nutans has priority. However, the plant described by Aiton (1789) was not pondcypress; rather, it was a long-leaf, drooping form of baldcypress (Watson, 1983). Therefore, imbricaria has priority (Watson, 1983). The name imbricaria became imbricarium in 1837 when Croom (1837) classified pondcypress as a botanical variety of $T$. distichum (Watson, 1983). The correct botanical name for pondcypress is $T$. distichum var. imbricarium (Nutt.) Croom adopted by modern authors (Lickey and Walker, 2002; Lickey et al., 2002; Tsumura et al., 1999; Watson, 1983, 1993).

Nomenclature of montezuma cypress is much less complicated. When it is treated as a distinct species, the name is $T$. mucronatum Tenore (Arnold, 2002; Liberty Hyde Bailey Hortorium, 1976; Creech and Yunlong, 2003; McMillian, 1974; St. Hilaire, 2001; Turner and Watson, 1999; Vines, 1960). However, because the most appropriate taxonomic treatment is as a botanical variety, the correct botanical name is $T$. distichum var. mexicanum Gordon (Watson, 1983).

In summary, we suggest the following classification of Taxodium: baldcypress ( $T$. distichum var. distichum), pondcypress (T. distichum var. imbricarium), and montezuma cypress ( $T$. distichum var. mexicanum). See Table 2 for an abbreviated list of synonymy of the three taxa.

\section{Literature cited}

Aiton, W. 1789. Hortus kewensis. George Nicol, London.

Arnold, M.A. 2002. Landscape plants for Texas and environs, 2nd ed. Stipes Publishing, Champaign, Ill.

Bresnan, D.F., W.A. Geyer, and G. Rink. 1996. Variation among green ash of differing geographic origins outplanted in Kansas. J. Arboriculture 22:113-116.

Correll, D.S. and M.C. Johnston. 1970. Manual of the vascular plants of Texas. Texas Research Foundation, Renner, Texas.

Creech, D. and Y. Yunlong. 2003. Taxodium $\times$ 'Nanjing Beauty': A new landscape plant for the south. HortScience 38:1292-1293(abstr.).

Croom, H.B. 1837. Cat. Pl. New Bern, N.C.
Giridhar, J., B. Pai, and W.R. Graves. 1995. Seed source affects seedling development and nitrogen fixation of Maackia amurensis. J. Environ. Hort. 13:142-146.

Greuter, W., J. McNeill, F.R. Barrie, H.M. Burdet, V. Demoulin, T.S. Filgueiras, D.H. Nicolson, P.C. Silva, J.E. Skog, P. Trehane, N.J. Turland, and D.L. Hawksworth (eds.). 2000. International code of botanical nomenclature (St. Louis Code). Regnum Vegetabile 138. Koeltz Scientific Books, Königstein, Germany.

Griffiths, M. 1994. The new Royal Horticultural Society dictionary: Index of garden plants. Timber Press, Portland, Ore.

International Plant Names Index. 2006 The International Plant Names Index. 12 June 2006. <www.ipni.org/ipni/plant search? request_type=search \&output_ format $=$ query $\&>$.

Krüssmann, G. [H. Warda (ed.), M. Epp (trans.)]. 1985. Manual of cultivated conifers. Timber Press, Portland, Ore.

Liberty Hyde Bailey Hortorium. 1976. Hortus third: A concise dictionary of plants cultivated in the United States and Canada. Macmillan, New York.

Lickey, E.B. and G.L. Walker. 2002. Population genetic structure of baldcypress (Taxodium distichum [L.] Rich. var. distichum) and pondcypress (T. distichum var. imbricarium [Nuttall] Croom): Biogeographic and taxonomic implications. Southeastern Naturalist 1:131148 .

Lickey, E.B., F.D. Watson, and G.L. Walker. 2002. Differences in bark thickness among populations of baldcypress [Taxodium distichum (L.) Rich. var. distichum] and pondcypress [T. distichum var. imbricarium (Nuttall) Croom]. Castanea 67:33-41.

Linnaeus, C. 1753. Species plantarum. Impensis Laurentii Salvii, Stockholm, Sweden.

McMillian, C. 1974. Differentiation in habitat response in Taxodium distichum, Taxodium mucronatum, Platanus occidentalis, and Liquidambar styraciflua from the United States and Mexico. Vegetation 29:1-10.

Middleton, B.L. and K.L. McKee. 2004. Use of a latitudinal gradient in bald cypress (Taxodium distichum) production to examine physiological controls of biotic boundaries and potential responses to environmental change. Global Ecol. Biogeography 13:247-258.

Missouri Botanical Garden. 2006. VAST nomenclatural database and associated authority files. 12 June 2006. <http://
mobot.mobot.org/W3T/Search/vast. html>.

Murphy, J.B. and R.G. Stanley. 1975. Increased germination rates of baldcypress and pondcypress seed following treatments affecting the seed coat. Physiol. Plant. 35:135-139.

Nuttall, T. 1818. The genera of North American plants. Vol. 2:224 (1971. Facsimile of 1818 ed.). Hafner Publishing, New York.

Richard, L.C.M. 1810. Note sur les plantes dites conifers. Annales du muséum national d'histoire naturelle 16:296299.

Schopmeyer, C.S. 1974. Seeds of woody plants in the United States. USDA Handbook no. 450. Forest Service, USDA, Washington, D.C.

Schrader, J.A. and W.R. Graves. 2000. Seed germination and seedling growth of Alnus maritima from its three disjunct populations. J. Amer. Soc. Hort. Sci. 125:128-134.

Shoemake, L.J., M.A. Arnold, and F.T. Davies, Jr. 2004. Provenance impacts transplant establishment and adventitious root regeneration of sycamore. J. Amer. Soc. Hort. Sci. 129:360-367.

St. Hilaire, R. 2001. Seed coat treatments influence germination of Taxodium mucronatum. Desert Plants 17:15-18.

Tsumura, Y., N. Tomaru, Y. Suyama, and S. Bacchus. 1999. Genetic diversity and differentiation of Taxodium in the southeastern United States using cleaved amplifies polymorphic sequences. Heredity $83: 229-238$.

Turner, R.G., Jr. and E. Watson (eds.). 1999. Botanica. Barnes \& Noble, New York.

U.S. Department of Agriculture. 2006. USDA national plant germplasm system. 12 June 2006. <www.ars-grin.gov/npgs/ searchgrin.html>.

Vines, R.A. 1960. Trees, shrubs and woody vines of the Southwest: A guide for the states of Arkansas, Louisiana, New Mexico, Oklahoma, and Texas. University of Texas Press, Austin, Texas.

Watson, F.D. 1983. A taxonomic study of pondcypress and baldcypress. N.C. State Univ., Raleigh, PhD Diss.

Watson, F.D. 1993. Taxodium Richard, p. 403-404. In: Flora of North America Editorial Committee (eds.). Flora of North America north of Mexico. Oxford University Press, New York.

Wood, B.W., L.J. Grauke, and J.A. Payne. 1998. Provenance variation in pecan. J. Amer. Soc. Hort. Sci. 123:1023-1028. 